\title{
Virtuelles Testen \\ von kohlefaserverstärkten \\ Kunststoffbauteilen bei Airbus
}

Dr. Wolfgang Wohlers, Airbus Operations $\mathrm{GmbH}$

Vortrag lag zu Redaktionsschluss nicht vor.

Vielen Dank für Ihr Verständnis. 